Open Access

\title{
The perceived effectiveness of democratic management, job performance, and citizenship behavior: evidence from a large Chinese state-owned petrochemical company
}

Fuxi Wang

\author{
Correspondence: wangfuxi@uibe. \\ edu.cn \\ Business school, University of \\ International Business and \\ Economic, No. 10 Huixin East Street, \\ Chaoyang District, Beijing 100029, \\ People's Republic of China
}

\begin{abstract}
Democratic management, a unique union-based form of employee participation in China, is seldom studied in the employee participation literature. This paper investigates the associations between employees' perceived democratic management effectiveness, employee job performance and organizational citizenship behavior (OCB), using 988 matching surveys of both workers and their supervisors in a state-owned petrochemical firm from the central region of China. We find that our measure of an employee's perception of democratic management effectiveness is positively associated with an employee's job performance and organizational citizenship behavior. However, the association between perceived democratic management effectiveness and employee performance is negative if the employee is a dispatch worker. Our interpretation of the findings suggests that an employee's perception of democratic management effectiveness is a source of employee performance.
\end{abstract}

Keywords: Democratic management, Worker's congress, Petrochemical industry, Dispatch worker, Job performance, Citizenship behavior

\section{Introduction}

Democratic management is a union-based employee participation institution unique to China. It "refers to labor having rights as employees, to participate in the operation and management of their work units (enterprises or government organs) or be involved in the affairs that concern their material interests" (Taylor et al., 2003). The right to participate in democratic management in practice has a lot in common with classical management participation in much of Western Europe (Taylor et al., 2003). However, unlike co-determination in Germany (e.g., Gurdon and Rai, 1990; Addison et al., 2000), democratic management in the Chinese context is ignored and inadequate attention is paid to this topic in the participation literature.

Most of the prior research on democratic management and the workers' congress, the elemental form of democratic management, focuses on how democratic management (or the workers' congress) could protect workers' democratic rights and well-being, assuming

(c) The Author(s). 2018 Open Access This article is distributed under the terms of the Creative Commons Attribution 4.0 International License (http://creativecommons.org/licenses/by/4.0/), which permits unrestricted use, distribution, and reproduction in any medium, provided you give appropriate credit to the original author(s) and the source, provide a link to the Creative Commons license, and indicate if changes were made. 
that the major function of the institution is to defend employees interests by granting them voice (Chen and Chan, 2004, 2010; Zhu and Chan, 2005; Philion, 2007; Yu, 2011). Empirical works so far find that employees' evaluation of the effectiveness of their workers' congress is positively associated with the protection of workers' occupational health and safety (Chen and Chan, 2004); that the workers' congress could foster consensus industrial relations (Zhu and Chan, 2005); and that employee participation through a workers' congress is positively related to firm productivity $(\mathrm{Li}, 2004)$. Few study has attempted empirical tests of democratic management beyond the workers' congress. In addition, little attention has been directed to another function of democratic management improving performance, which has always been a priority issue for management (Taylor et al., 2003). The academic attention to democratic management mismatches its importance. Therefore, one crucial question remains unclear: Does democratic management matter to firms?

Li's (2004) paper makes the first attempt to study the effect of employee participation in workers' congresses on firm performance based on a provincial survey of 1000 largeor medium-sized enterprises. In this study, Li shows that employee participation in workers' congresses has a positive effect on firm performance. However, no research has examined the implication of the perceived democratic management effectiveness on employee performance at the individual level.

We evaluate the effectiveness of democratic management as perceived by employees against two metrics: Employee job performance and organizational citizenship behavior (OCB), as assessed by their direct supervisor. Employee job performance reflects how well the employee does their assigned tasks, while OCB indicates how much effort he or she exerts on extra-role behaviors, such as helping colleagues with their work. We start by identifying democratic management as an integrated form of employee participation and then introduce a debate on the effectiveness of democratic management. Following that, we analyze the relationship between democratic management effectiveness perception and employee job performance. Literature on both employee participation and work councils in Germany provides support for the association between democratic management and performance (Addison, 2000; Addison et al., 2004). In addition, a unique feature of democratic management practices in the Chinese context is discussed to elaborate the relationship.

We then examine the association between democratic management effectiveness perception and OCB. To substantiate the relationship, we draw on theories of procedural justice, perceived supervisor support and psychological ownership to endorse the logic. Psychological ownership, especially, captures the concept of employees being "masters of enterprises" in stated-owned enterprises (SOEs) (Clarke et al., 2004). This paper makes the attempt to empirically investigate the instrumental function of democratic management at the individual level, and provides empirical evidence for managers on why implementing this institution would be beneficial to their firms.

The article proceeds as follows. In Section "Democratic Management", we first conceptualize democratic management as a form of employee participation in China, which we follow with a discussion of perceived democratic management in relation to employee job performance and citizenship behaviors. In Section "Democratic Management and Employee Performance", we describe the survey data, operationalization of variables, and set out the analysis strategy. In Section "Data and Operationalization", we present and discuss the empirical results. The article ends with a discussion of the findings and conclusions. 


\section{Democratic management}

Democratic management is a union-based employee participation institution unique to China. It "refers to labor having rights as employees, to participate in the operation and management of their work units (enterprises or government organs) or be involved in the affairs that concern their material interests" (Taylor et al., 2003). Democratic management was designed and enforced by the central government of China to fulfill the ideological premise that workers are the masters of the state, and to serve the function of moderating tensions between manager and labor (Zhu and Chan, 2005).

In the last twenty years, the foreign direct investment (FDI) in China has had a dynamic impact on the SOEs. The consequence of the evolution of foreign ownership has two aspects: (1) the marginalization and fragmentation of labor, and (2) the increase in the degree of managerial autonomy (Gallagher, 2005). The influence of workers in SOEs through democratic management, in this new context, is affected by these trends. Research has focused on the inability of workers' congresses to buttress workers' democratic appeals (Philion, 2007; Yu, 2011), and the lack of independence of workers' congresses from management level (Clarke et al., 2004; Ng, 1984).

\section{Democratic management as a form of employee participation in China}

The "Regulations on the Workers' Congresses in State-owned Industrial Enterprises" was officially introduced by the State Council of China in 1986, marking the institutional origin of democratic management as presently conceived. In this regulation, the workers' congress is adopted as the main department for the practice of democratic management, and is the institution by which workers exercise their rights to democratic management (Taylor et al., 2003: 139). As described by Yu (2011), the prominence of the workers' congress in China has a cyclical pattern, with sudden surges in activity and lapses into formalism. The 1988 Enterprise Law provided significant power for employee representatives. Employee representatives could review major management decisions, approve or disapprove of wage and bonus distribution schemes, decide the use of a firm's welfare fund, and elect the manager of the enterprise (Li, 2004). However, the 1993 Corporate Law significantly reduced the power of employee representatives. The new law no longer empowers employee representatives with the rights listed above; instead, the law only requires that management consult with employee representatives before making final decisions (Li, 2004).

Recently, "Provisions on the Democratic Management of Enterprises"(hereinafter referred to as "Provision") was jointly issued by the All-China Federation of Trade Unions (ACFTU), together with five other Chinese authorities in 2012, indicating another change in the national legal regulations on democratic management and workers' congresses in China. The five authorities include the Central Commission for Discipline Inspection, the Organization Department of the CPC Central Committee, the Central Commission for Discipline Inspection (SASAC), the Ministry of Supervision, and the All-China Federation of Industry and Commerce (ACFIC). Although the "Provisions" do not carry the force of law, the execution of these authorities should not be underestimated. The "Provisions" stipulate three major practices to facilitate organizations to execute democratic management, including the workers' congress, the employee director and supervisor (EDS) and "open corporate affairs (OCA)". One advance of the "Provisions" is that, in line with other 
local regulations on democratic management (Hubei province) and on workers' congresses (Shanghai), the regulations apply to all types of enterprises, including state-owned and privately-owned enterprises. In other words, the implementation of democratic management systems and workers' congresses should not be limited to state-owned enterprises. In 2012, 84.4\% of SOEs (236,129 firms) established an OCA unit, while among all unionized non-SOEs, 84.6\% (4891,257 firms) have established OCA units. Meanwhile, $88.1 \%$ of state-owned enterprises have workers' congresses, while in unionized non-SOEs, the percentage is $85.5 \%$. Therefore democratic management is expected to play an increasingly important role in helping employees' participation in firm operations and management in the coming years.

Traditionally, SOEs are "owned by the whole people," and the workers, "masters of the enterprises," share a common commitment to the firm. Both Ng and Warner (1998:84-5) and Clarke et al. (2004) acknowledge that within the institutionalized democratic management system, employees and employers have a unity of interests. In a sense, it is consistent with the unitary assumption of participation schemes in management literature. As stated in "Provisions", one of the objectives of democratic management is to promote the sustainable development of the company. These substantiate the similarity of democratic management with classic management participation.

One the other hand, democratic management is slightly different from both participation in decision-making in the management literature (Wagner, 1994) and co-determination in Germany. Unlike co-determination in Germany, China's unions are highly involved in developing the democratic management system. First, trade unions are closely involved in the institutionalization and implementation of democratic management. The ACFTU, the only legitimate union organization in China, acts as the major player to promote the legalization of workers' congresses, OCA and democratic management. As well, the enterprise union, the branch of the ACFTU at the company level, is supposed to collect suggestions from employees before the meeting of the workers' congress, to deal with workers-related issues in congress meetings, and, according to the "Provisions," the union chair or deputy chair must be the candidate of the employee directive and the supervisor directive (Chen and Chan, 2004; Yu, 2011). Second, the overarching role of the Chinese Communist Party also distinguishes democratic management from management-driven participation schemes in SOEs. According to the "Provision," democratic management in the enterprise is supported, instructed and supervised by the corporate Party committee. In SOEs, both the enterprise union and the management are under the direct guidance of the Communist Party (Yu, 2011). Party committees in SOEs have a major say on important issues in the company, including the nomination of top management team and union officials. Therefore, Party committees in SOEs are able to facilitate the implementation of democratic management by lessening resistance from both management and labor, and to amplify its effects on the firm by attaching political meanings to the schemes to mobilize employees.

\section{Workers' congress: the core form of democratic management}

A workers' congress, also known as a "Staff and Worker Representative Congress" (SWRC), "Employee Representative Congress" (ERC), or "Worker Representative Congress" (WRC), is the core form of democratic management. Workers' representatives 
are elected directly from ordinary workers and convene once or twice a year to discuss important issues at the company level. The workers' congress is not a trade union body, but an instrument for the participation of workers in the management of enterprises (Clarke et al., 2004). According to the "Provisions", a workers' congress has legal rights in several aspects: (1) to be consulted on major strategic policies of the enterprise, including annual production plans, firm reform, and formulation of important firm rules; (2) to be consulted on how to use the workers' welfare fund, the distribution of welfare apartments (apartments constructed by the company and sold to employees at low prices) among employees and all important issues concerning workers' welfare; (3) to decide on the draft of collective contracts; (4) to elect and dismiss employee directors and employee supervisors, and to recommend or elect managers according to their mandate; (5) to monitor the performance of managers at all levels and to make suggestions for rewarding or penalizing them (Labor Contract Law, Article 13). Workers' congress has taken an increasingly important role in Chinese legal systems. The "Labor Contract Law" in 2008 requires that enterprises follow democratic procedures, such as the operation of workers' congresses, and the discussion of rules and decisions with employees when it formulates or amends any company rules and institutions or makes any important decisions that are directly related to the interests of the employees (Labor Contract Law, Article 4). Failure to do so will negatively impact a firm's in labor dispute resolutions. ${ }^{1}$

"Employee director" and "employee supervisor" represent employees' rights and interests on the Board of Directors and Board of Supervisors, possessing equal power to other directors and supervisors (Taylor et al., 2003). The Corporate Law (1995) establishes the legal status of the EDS. In 2011, approximately 85,000 unionized companies had employee directors, rising from 29,000 in 2005; 83,000 unionized companies had employee directors, rising from 24,000 in 2005. In Chinese SOEs, employee directors and employee supervisors participate directly in management decision-making on the board. According to the "Provisions," both the employee directors and employee supervisors are nominated by the union, and elected through the workers' congress. The union chair and vice chair should be listed as candidates for these two positions.

OCA, similar to "information sharing," is a practice initiated to foster direct communication between management and employees and to protect employees' "right to know" (Taylor et al., 2003). Dating back to 1994, OCA was first practiced in a tractor company in Shijiazhuang. The common ways that unions execute the practice of OCA include: posting detailed evaluations of everyone's monthly performance on a public board so that workers know why their wages are lower or higher than others; worker representatives debrief and distribute information reported in the workers' congress to rank-and-file employees; and, before decisions on major issues are made, information is distributed through internal networks (Liu, 2007).

\section{Other forms of democratic management}

In addition to the three practices of democratic management as stated in the "Provisions": Workers' congress, EDS and OCA, we also summarize four other practices that, based on prior literature and interviews with Chinese industrial relations scholars and union chairs in SOEs, are considered to be commonly used in practice. The other four 
practices are: "rationalization proposals," "factory director reception day/factory director mail box," "collective consultation," and "grass-roots democratic participation institutions (e.g., democratic forum, democratic management panel)."

"Rationalization proposals" are an input mechanism through which employees are able to make suggestions about productivity improvement, working conditions, and employee welfare and benefits. The first regulation in "Rationalization Proposals and Technical Improvements Awards Regulations (Rationalization proposals)" issued by the State Council in 1982, have been popular among companies as a motivational practice to enhance productivity and encourage innovation (Liu, 2007). If the "Rationalization proposals" are used well, feedback from relevant departments are enforced. Even if some problems cannot be solved right away, an explanation is given to employees.

A "factory director reception day/factory director mail box" policy, similar to an "open door" policy, enables direct communication between the factor director and employees. Workers can make suggestions, ask questions, and seek feedback on the issues they are concerned with, including working conditions, salary and benefits, company plans, etc. This policy reduces the hierarchical obstacles to transferring information.

"Collective consultation" is an institution through which the union chair negotiates collective contracts with managers. However, this institution has been established to secure "harmonious labor relations" and emphasizes the unity of interest between employees and management. Unions in China do not have the right to organize a strike, so Chinese unions in general have little leverage at the negotiation table. At the present stage, collective consultation is essentially a development of "workers" participation in management (Clarke et al., 2004), rather than a real collective bargaining system. The subordination of the trade union to management priorities partially discourages the collective consultation system from becoming collective bargaining.

"Grass-roots democratic participation institutions," such as a team meeting, is a direct form of employee participation. Employees share information with supervisors as equals in a panel or meeting, complaining or making suggestions on any issues in the workplace. Also, employees discuss production or work plans, regulations within the team and the distribution of bonuses among team members in these meetings. As well, employees evaluate and even elect supervisors under the instruction of higher-level managers.

Democratic management is an integrated participation system. The different practices of democratic management are the operational methods by which employees speak for their rights and are involved in democratic management. First, the seven practices of democratic management enable employees' participation in decision making at different levels. At the organizational level, the workers' congress, employee director and employee supervisor system and collective consultation offer employees the opportunity to have a say in the company's decision making procedures. At the annual meeting of a workers' congress, workers representatives can make suggestions on issues that are directly related to the interests of the employees before final decisions are made. The employee directors and employee supervisors act as representatives of employees by exercising their voting rights on major company issues during board meetings. The union can initiate collective consultation on wages with the management and negotiate higher wages and better benefits. At the team level, employees are able to have influence on their tasks and working conditions through grass-root democratic management institutions. Supervisors are obligated to disclose information concerning production 
and employee interests to workers, and workers can discuss task arrangements and distribution of benefits within the team through these panels. Second, the seven practices of democratic management enable the flow of information between employees and management. Employees can have easy access to information concerning their interests through OCA arrangements, and management can receive input from employees through the "factory director mail box" or "rationalization proposal" practices. Therefore, we believe the seven practices of democratic management function as an integrated employee participation system and contribute to both the productivity of the firm and the protection of employees' rights and interests.

\section{Debates on the effectiveness of democratic management}

The debate on the effectiveness of democratic management focuses on whether the workers' congress is an effective institution on paper or in practice. On the one hand, prior literature on democratic management focused on the inability of workers' congresses to buttress workers' democratic demands and its failure therefore to stop the privatization of SOEs (Philion, 2007; Yu, 2011). They note that the lack of independence of workers' congresses from management level limits the ability of trade unions to enforce collective bargaining (Clarke et al., 2004), prevents workers' congresses from supporting the formulation of self-management in Chinese factories (Ng, 1984), and leads to the failure to stop privatization of SOEs during waves of SOE reform ${ }^{2}$ (Yu, 2011). Yu (2011) explains that a workers' congress cannot be effective, because, otherwise, employees would have real control over their workers' congress, and the struggle between those supporting the privatization of state-owned enterprise (mainly management who took orders directly from the government) and those opposing it (mainly workers who would suffered loss of job security from the reforms) during the SOE reforms would have been more intense and widespread.

On the other hand, some research has provided support for the effectiveness of the workers' congress. Zhu and Chan (2005) describe a case in which an employee in a science institute suddenly found the workers' congress a powerful tool to distribute research funding and the workers' congress became a useful consultation mechanism between workers and management. Furthermore, Zhu and Chan use the 1997 national survey conducted by ACFTU, to provide evidence in support of the fact that the Chinese workers' congresses are not as useless as conventional wisdom holds, and some workers do give their workers' congresses positive evaluations. The qualitative work and quantitative work done by Chen and Chan $(2004,2010)$ also support the effectiveness of workers' congresses. Although the mere existence of a workers' congress does not affect the Occupational Health and Safety (OHS) system, the enterprise level workers' congress does have a significant impact on the protection of employees' health and safety. For example, bivariate analyses show that employees in enterprises with ineffective workers' congresses are much more likely to report ineffectiveness or poor quality in the design, facilities, and implementation of their factory's OHS system. The results provide some evidence to challenge the widely ingrained perception that the workers' congress is "useless" (Chen and Chan, 2004, 2010).

\section{Democratic Management in X Petrochemical Company}

The X Company we study is a large state-owned petrochemical company located in the central region of China, where democratic management practices are relatively well-preserved, 
and is relatively geographically isolated from other places and is the dominant enterprise in the city where it is located. The company was established in the 1950s and has approximately 55,000 employees. It is composed primarily of state contract workers (or regular workers), and dispatched workers as well as a few temporary workers who are paid by working hour. Temporary workers make up less than $1 \%$ of the work force. There are two types of dispatched workers in this company, dispatched workers who are the offspring of regular workers, and dispatched workers who are not. The proportion of dispatched workers and regular workers varies with workshops. The dispatched workers are paid approximately $75 \%$ of the payment for regular workers doing the same job, and promotion opportunities to the companies that share the same parent company are only offered to regular workers. However, promotion opportunities for both regular workers and dispatched workers within the company are the same and dispatched workers have an opportunity to transfer to regular workers if they perform well.

The X Company incorporates all seven democratic management policies that we have reviewed so far. The workers' congress is strictly established at the company level, plant level and workshop level. The workers' congress meeting is held once a year at each level, and the workers' congress representative committees are in charge of issues between the two meetings, including collecting proposals, and supervising the enforcement of the proposals passed during the meetings. Employee representatives at the company level and plant level are issued an "Employee Representative Work Manual" that specifies the work obligations, the names of employees they need to contact and their contacts, and indicates that they are supposed to collect proposals and suggestions on a regular basis. $32.7 \%$ of employee representatives at the company and plant level are nominated and elected directly from employees, while $61 \%$ of them are nominated by the Party committees and elected by employees. The X Company integrates OCA with internal control, which refers to a set of work procedures executed corporately by all employees. Certain information is released to employees at fixed stages of the work process in the forms of the workers' congress, open corporate affairs board, the internet, newspaper, etc. Mainly, the information includes major company decisions, important production and management issues, the interests of employees, etc. The union chair and vice chair have the positions of employee director and employee supervisor, but not all interviewees know what they do and who are in the positions. "Rationalization proposals" are collected constantly by employee representatives, and the frequency varies by workshop. Proposals are handed to the union and feedback is required within 10 days. In 2011, the union collected 3378 rationalization proposals and 2129 have been adopted. The "factory director reception day/factory director mail box" policy has been established in some of the workshops. Collective consultations take place at both the company level and plant level. Collective contracts on compensation, working hours, vacations, health and safety, and insurance and benefits are negotiated between the union and management level, passed at the workers' congress meeting and signed by the union chair and head of management. Sixty-four violations of collective contracts were discovered and corrected under the union's inspection in 2011. Different forms of grass-roots democratic participation institutions are employed in different plants. For example, one plant holds annual meetings between the head of the plant and employee representatives. Suggestions are taken and questions answered at the scene. The head of plant also reports to employee representatives about the state of operation of the plant. 


\section{Democratic management and employee performance \\ Perceived effectiveness of democratic management and employee performance}

As Schregle (1970) states, "everyone who employs the term (participation) thinks of something different." Narrowly defined, participation is a process in which influence is shared among individuals who are otherwise hierarchical unequals (Locke and Schweiger, 1979). Broadly speaking, the definition can be extended to a wide variety of instances in which subordinates are accorded greater personal influence through delegation, consultation, etc. (Leana, 1986; Vroom and Jago, 1988). Economists (Levine, 1990), management scholars (Wagner, 1994; Cotton et al., 1988) and IR scholars (Cooke, 1994) generally agree that (1) participation usually has a positive, small effect on productivity or performance; (2) the size and significance of the effect are contingent on the type of participation involved and on the industrial relations environment; (3) substantive rather than consultative participation has positive long-term effects on productivity, and enables a high degree of employee commitment and employee-management trust. However, the debate on the ability of participation to affect performance (Locke and Schweiger, 1979; Schweiger and Leana, 1986) and on whether forms of participation matter (Cotton et al., 1988; Cotton et al., 1990; Wagner, 1994) challenges the conclusions reached by these economic and management scholars.

Similarly, mixed results have been found regarding the relationship between mandatory work councils and firm performance (Addison and Wagner, 1997; Addison et al., 2000; Addison et al., 2001; Mueller, 2011). Many studies on worker councils have revealed a positive relationship between the establishment of works councils and performance (Addison et al., 2000). For example, mandatory work councils do not impair, and may improve, the performance of larger German organizations (Addison et al., 2000). When utilizing self-reported subjective measures, the effect of work council on profit is negative; with objective measures, however, the effect of work council on profits is positive and significant (Mueller, 2011). Addison et al. (2004) find that German work councils have a positive impact on organization productivity. However, previous studies using a self-reported subjective evaluation of profitability as the dependent variable (e.g., Addison and Wagner, 1997; Addison et al., 2001) typically have found a negative relationship between work councils and profits.

Specifically, employee participation schemes affect individual employee performance by providing employees with greater intrinsic rewards from work. Employees have higher job satisfaction when they have a say about their work, which in turn increases employees' motivation to achieve new production goals (Miller and Monge, 1986; Wagner, 1994). As well, if employees are given more access to management information, they are more likely to develop trust and commitment to organizational goals (Wagner, 1994), which lead to better work performance.

Literature on the participation-performance relationship and work council-performance relation show that involving employees in the decision-making process is likely to result in favorable performance. Democratic management is a form of employee participation in China similar to co-determination in Germany (Taylor et al., 2003). Thus, we may expect a positive relationship between democratic management and performance. Taylor et al. (2003) have stated that democratic management is supposed to "have the motivational function of stimulating workers' enthusiasm to engage in production, to encourage them to cooperate with management in fulfilling the economic targets specified by the owners". The direct impact of having participation implemented in a company is that communication 
channels are open in multiple directions, through mechanisms such as workers' congresses or grass-root democratic management panels, resulting in greater and more accurate information flows (Mitchell, 1973). First, through feedback and information exchange between employees and management in democratic forums and other grass-root democratic management institutions, it is clearer to employees which behaviors are rewarded or punished. Accurate expectations about the effort-performance relationship can lead employees to make more effort. Second, through participation procedures as workers' congresses, collective consultation and rationalization proposals, employees are able to influence working conditions and the reward structure. They are able to choose the rewards they value most, which will give them the strongest incentives. Third, participation increases exposure of employees to leaders and superiors, so that they have a better chance for promotion. Our interviews with the employees of this state-owned enterprise shows that those who are elected as worker representatives, who excel in labor competition, and who are active in submitting rationalization proposals are more likely to be given opportunities and be promoted to higher positions. Therefore, democratic management policies themselves may provide motivation for higher employee performance.

Given some special features of democratic management, this participation scheme may also contribute to improving employee performance through other mechanisms. The involvement of the government in promoting democratic management may attach political overtones to this participation scheme. In SOEs, workers depend on their firms and supervisors for many things other than income, such as social identity, career opportunities, access to company housing and other public goods controlled by their supervisors, and official approvals bypassing the normal process in formal regulations (Walder, 1986). In particular, employment in SOEs establishes workers' superior social identity and rights to specific distribution and welfare, such as welfare housing ${ }^{3}$ (Taylor et al., 2003), which are benefits generally regarded as unique to SOEs. Therefore, employees are more likely to show political loyalty (Walder, 1986) by supporting the objectives set through political mobilization by government in return for the benefits granted to them (Gouldner, 1960). Furthermore, it is common practice that the government sets production objectives for SOEs and mobilizes employees to achieve these objectives for a greater purpose such as the development of the country. Employees from SOEs, therefore, may reframe the meaning of their work. When they integrate themselves into the functioning of a state-owned enterprise, they are able to see their work as contributing to the prosperity of their country and to see themselves as a crucial part of the process. Employees in SOEs may make sense of why their work matters and be more motivated to work in compliance with objectives set by the government (Wrzesniewski and Dutton, 2001). The policies of democratic management, such as "rationalization proposals" and OCA, are often implemented in SOEs by the government in the form of political mobilization. Both union officials in the firm and managers intensely propagandize the political meanings attached to these participation policies, and argue that these policies are intended to protect employees' right to know and right to voice as citizens. For employees, these incentives to comply could be either based on "a deep-seated particularism in the allocation of material rewards and career opportunities" (Walder, 1986), or be based on reframing the meaning of work. This political aspect of democratic management may shape employee attitudes towards work, increase acceptance of the company's democratic management policies and production 
decisions, and promote production. Although political mobilization is decreasing its impact as the market becomes more influential, the political overtones of democratic management policies are still impactful in this new context because SOEs can reinforce employees' political loyalty by maintaining ties between party authorities and employees through rights to specific distributions and welfare provided by the state, especially in SOEs geographically isolated from alternative workplaces for employees.

Given the logic described above, effectively implemented democratic management would predict high performance. The effectiveness of democratic management as perceived by employees is reflected through three aspects: an employee's right to know, to participate and to voice. Effective democratic management is designed to fully protect these three employee rights. An employee's right to know is realized through the workers' congress, OCA, the employee directors and supervisors, and grass-root democratic participation institutions. Similarly, an employee's right to voice is accomplished through the workers' congress, the employee directors and supervisors, rationalization proposals, and the factory director reception day and factory director mail box. Likewise, an employee's right to participate in decision-making is achieved through the workers' congress, the employee directors and supervisors, collective consultation, and grass-roots democratic participation institutions. Therefore, employees who perceive the policies of democratic management as effective may also demonstrate higher job performance.

OCB refers to individual behavior that is performed voluntarily, is not explicitly recognized by the formal reward system, and that in aggregate contributes to organizational effectiveness (Organ, 1988). OCBs in the U.S. context and in the Chinese context share some common dimensions, including altruism, conscientiousness and identification with the company (referred to as civic virtue in the U.S. literature) (Hui et al., 1999). Altruism refers to an employee voluntarily helping colleagues with their work. Conscientiousness refers to employee behaviors that go beyond the minimum role requirements of the organization, which includes adherence to rules of work procedures and conduct (Smith et al., 1983). Identification with the company refers to employee behaviors that indicate involvement in the overall well-being of the organization (Organ, 1988). Hui et al. (1999) identify two other dimensions applicable to the Chinese context: "interpersonal harmony" and "protecting company resources". Interpersonal disharmony refers to "negative employee behaviors that aim at personal power and that have a detrimental effect on others", which, to some extent, captures the reverse meaning of altruism, but focuses more on interpersonal relationships. Similarly, destroying company resources refers to "negative employee behaviors that involve the abuse of company resources (e.g., company phones, copy machines, computers, and cars), and policies to satisfy personal means", which broadly represents the reverse meaning of conscientiousness, but focuses more on protecting company resources.

One motivational factor for OCB is the perception of fairness, particularly the perception of procedural justice (Deluga, 1994a; Konovsky and Pugh, 1994b; Konovsky and Organ, 1996a; VanYperen et al., 1999). Participation in decision making shapes how employees view the fairness of procedures (Folger, 1977). According to Deutsch (1975: 139), employees are more likely to accept decisions and consequences if they have participated in making them. Reasons for making decisions and concerns from all sides are fully discussed during the participation process, so that the final decisions are more likely to be accepted. If the process is perceived as fair by allowing for participation, it is more likely that the resulting outcomes would be considered fair as well. Democratic management as a participation system allows 
for fairer procedures in task arrangement, benefit distribution, workplace rules-making and wage determination, which increase employees' perception of procedural fairness. According to social exchange theory and norms of reciprocity (Gouldner, 1960), when employees feel that they are treated fairly, one possible way to "pay back" is through higher levels of citizenship behaviors (Konovsky and Pugh, 1994b).

In view of similar rationales, a second motivational factor for OCB is perceived supervisor support (VanYperen et al., 1999). The opportunity to participate in decision-making implies a supervisor's respect for the rights of the individual employee and willingness to consider suggestions and complaints from subordinates. A high quality relationship between supervisor and subordinates is associated with OCBs (Farh et al., 1990; Deluga, 1995). OCB can be regarded as the way that employees maintain the quality of the relationship between employees and supervisor according to social exchange logic (VanYperen et al., 1999). Therefore, perceived effective democratic management might induce citizenship behaviors of employees by raising their perceived supervisor support.

A third motivational factor for OCB is psychological ownership. "Psychological ownership is the psychologically experienced phenomenon in which an employee develops possessive feelings for the target" (Van Dyne and Pierce, 2004). This feeling of "mine" could cause proactive behavior aimed at enhancing the target of ownership, (Wilpert, 1991) and at defending their plants against theft and other forms of resource misuse (Yu, 2011). Therefore, psychological ownership is likely to be positively associated with OCBs. In SOEs, traditionally, employees are regarded as "masters of the enterprise" (Clarke et al., 2004). Socialist ideology holds that workers, under common ownership, contribute to the industrialization of the country in general and to the development of "their own" plant in particular (Yu, 2011). However, the introduction of the market competition mechanism and the "directive responsible institution" have diminished employees' psychological ownership of the state-owned enterprise. The "iron rice bowl" (Kuruvilla et al., 2011), or lifetime employment, is no longer guaranteed and the idea of pure economic exchange relations with the firm is growing in SOEs. To maintain the "sense of possession" in SOE employees, democratic management could be used to strengthen the power and control of employees by valuing their say on important workplace issues, including lay-off decisions, evaluations of supervisors and the management, and approval of firm strategy and investment plans through the workers' congress. Furthermore, rationalization proposals offer employees the chance to exert some influence on workplace issues by making reasonable suggestions about technology and work conditions improvement. When employees develop a sense of belonging, efficacy and effectance (or sense of control), and self-identity based on a sense of possession, they are more likely to have a sense of responsibility and act in alignment with organizational objectives (Taylor et al., 2003; Van Dyne and Pierce, 2004), and be able to engage in discretionary actions. Therefore, we hypothesize that:

Hypothesis 1a:

Employees perceived effectiveness of democratic management is positively associated with their job performance.

Hypothesis $1 b$ :

Employees perceived effectiveness of democratic management is positively associated with their organizational citizenship behavior. 


\section{Moderating role of employment type}

Workers are fragmented along many different lines in Chinese factories, such as older "permanent" workers, younger contract workers, female production-line workers, male maintenance and supervisory workers, local workers and rural migrants (Gallagher, 2005).In general, employment types include "regular workers" and "dispatched workers", which evolved from the previous categorization of "formal workers" and "informal workers" respectively before the strong enforcement of the Labor Contract Law in 2008. Dispatched workers are workers sent by employment service agencies to the company requiring their service. The prevalence of dispatched employment arrangements in SOEs contributes to the flexibilization of employment relations in SOEs on the one hand, and precariousness and exploitation of dispatched workers on the other hand. Under this tiered employment system (Zhang, 2008), dispatched workers are treated differently regarding job security, benefits and welfare, promotion opportunities, and, in some cases, even pay level. According to Labor Contract Law, dispatched workers can only be hired for temporary, auxiliary or substitute positions, so that they are more likely to have less commitment to the firm and focus on the economic exchange with the employer. Even though some dispatched workers have the chance to "transfer" to regular workers, the policies are not applied to everyone. Those whose parents work in the same SOEs and those who excel at what they do have a higher chance to be "transferred," according to our interviews with workers.

Dispatched workers are in general under-represented in firms through democratic management institutions and workers' congresses. It is not until the recent implementation of "Provisions," effective in 2012, that dispatched workers were explicitly given the right to be elected as worker representatives for workers' congresses. In fact, dispatched workers are on paper excluded from the democratic management system before the "Provisions." And in practice, they are still not represented to the same degree as contract workers despite the implementation of the "Provision", and are therefore somewhat isolated from contract workers. One possible result of this underrepresentation is that dispatched workers feel more unfairly treated and more isolated from contract workers when they perceive that their company has installed a generally effective democratic management system, since the democratic management system mostly protects contract workers' rights. Consequently, democratic management may work as a discouragement rather than motivator for dispatched workers, and they may be less likely to exert extra effort to help co-workers or do their jobs. Therefore, even if dispatched and regular workers might equally perceive democratic management as an effective participation system, dispatched workers were less likely than regular worker to be responsive to it because they might have less attachment to the firm and care less about their "voice" in the firm.

\section{Hypothesis 2:}

Employment type will moderate the relationship between employee perceived effectiveness of democratic management and job performance, such that the positive relationship for regular workers will become negative for dispatched workers.

Hypothesis 3:

Employment type will moderate the relationship between employee perceived effectiveness of democratic management and OCB, such that what is perceived positively by regular workers will become negative for dispatched workers (Fig. 1). 


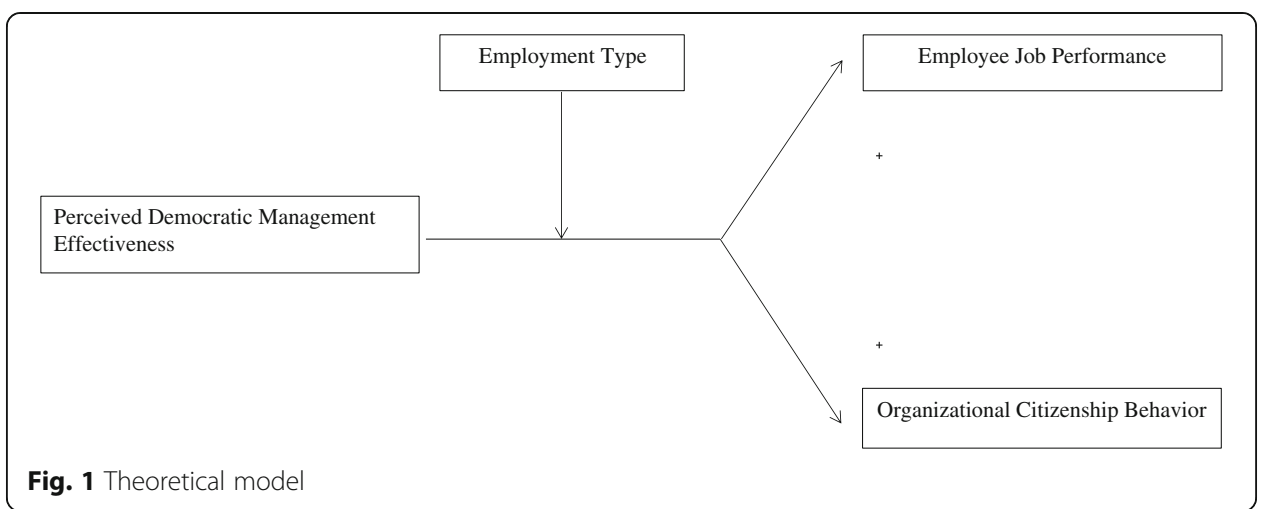

\section{Data and operationalization}

Data

To examine the effects of perceived democratic management on employee job performance and $\mathrm{OCB}$, we used quantitative survey data from 31 workshops ${ }^{4}$ in 6 plants in a state-owned petroleum company located in central China. We included all workshops in the 6 plants and randomly sampled, 19 to 60 employees in each workshop depending on the size of the workshop. The survey questionnaires were distributed and collected directly by the union representative of the workshop. We asked the union representative to randomly distribute the questionnaires to employees on the shift and to choose a group of workers that included representative demographic features (including gender, age and employment type). We used two sources of questionnaires to avoid a single source problem. We collected the independent variable (perceived democratic management effectiveness) from questionnaires asking the employees to evaluate the effectiveness of democratic management in the company. Dependent variables (employee job performance \& OCB) were rated by each employee's direct supervisor. We assessed the moderator variable (employment type) using survey responses from employees. Control variables were collected from the same survey. We visited several sites to make sure the procedures were properly followed. The survey data came from 988 employees and 151 supervisors. The average survey response rate was $89.8 \%$. There were 592 (63\%) male and 349 (37\%) female respondents, with a mean tenure of 17.6 years. Of the respondents, 839 (87\%) were union members of the current firm, and 125 (13\%) were non-union members or did not know their union status. Dispatched workers made up 24.5\% (238) of the workforce, while regular workers accounted for $75.5 \%$ (734). These statistics are consistent with the overall demographic distribution of the firm.

\section{Dependent variables}

The definitions of all variables, scales and coefficient alphas are provided in Table 1. We use two dependent variables to measure employee performance. Employee job performance is measured using a four-item scale based on Ashford, Lee, and Bobko's (1989) four-item measure. Items are listed in the table. Supervisors rated these items on a scale ranging from 1 ("strongly disagree") to 6 ("strongly agree"). The second dependent variable, OCB, is measured by the indigenous Chinese measure adapted by Hui et al. (1999) in a factory setting to capitalize on the cultural variance of measuring OCB. This measure of OCB was developed 
Table 1 Variables used in the present study

\begin{tabular}{|c|c|}
\hline Variable Name & Description \\
\hline \multicolumn{2}{|c|}{ Dependent Variables } \\
\hline \multirow[t]{5}{*}{$\begin{array}{l}\text { employee job } \\
\text { performance }\end{array}$} & $\begin{array}{l}\text { A respondent's job performance index value is the average value of the } \\
\text { following } 4 \text { items (measured on the same } 6 \text {-point scale } \\
(1=\text { strongly disagree; } 6=\text { strongly agree) })(a=0.92)\end{array}$ \\
\hline & 1. The performance level of this employee is satisfactory. \\
\hline & 2. This employee is effective in his or her job. \\
\hline & $\begin{array}{l}\text { 3. This employee performs better than many other employees who } \\
\text { perform the same job. }\end{array}$ \\
\hline & 4. This employee produces high-quality work. \\
\hline \multirow[t]{16}{*}{$\begin{array}{l}\text { organizational } \\
\text { citizenship } \\
\text { behaviors }\end{array}$} & $\begin{array}{l}\text { A respondent's OCB index value is the average value of the following } 15 \\
\text { items (measured on the same } 6 \text {-point scale } \\
(1=\text { strongly disagree; } 6=\text { strongly agree) })\end{array}$ \\
\hline & 1. Willing to assist new colleagues in adjusting to the work environment. \\
\hline & 2. Willing to help colleagues solve work-related problems. \\
\hline & 3. Willing to cover work assignments for colleagues when needed. \\
\hline & 4. Takes one's job seriously and rarely makes mistakes. \\
\hline & $\begin{array}{l}\text { 5. Complies with company rules and procedures even when nobody is } \\
\text { watching and no evidence can be traced. }\end{array}$ \\
\hline & 6. Does not mind taking on new or challenging assignments. \\
\hline & $\begin{array}{l}\text { 7. Eager to tell outsiders good news about the company and clarify } \\
\text { their misunderstandings. }\end{array}$ \\
\hline & 8. Makes constructive suggestions that can improve the operation of the company \\
\hline & 9. Actively attends company meetings. \\
\hline & 10. Often speaks ill of the supervisor or colleagues behind their backs. \\
\hline & $\begin{array}{l}\text { 11. Uses illicit tactics to seek personal influence and gain with harmful } \\
\text { effect on interpersonal harmony in the organization. }\end{array}$ \\
\hline & 12. Takes credit, avoids blame, and fights fiercely for personal gain. \\
\hline & $\begin{array}{l}\text { 13. Conducts personal business on company time } \\
\text { (e.g., trading stocks, shopping, and going to barber shops). }\end{array}$ \\
\hline & $\begin{array}{l}\text { 14. Uses company resources to do personal business } \\
\text { (e.g., company phones, copy machines, computers, and cars). }\end{array}$ \\
\hline & 15. Views sick leave as a benefit and makes excuses for taking sick leave. \\
\hline
\end{tabular}

Independent Variables

democratic An employee's perceived democratic management effectiveness is the average

management of 7 questions (measured on the same 4-point scale $(1=$ very bad; $4=$ very good)

1. How would you evaluate the effectiveness of the workers' congress in general?

2. How would you evaluate the effectiveness of the institution of OCA (e.g., open information through notice boards, workplace intranet, etc.)?

3. How would you evaluate the effectiveness of rationalization proposals?

4. How would you evaluate the effectiveness of factory director reception day and factory director mail box?

5. How would you evaluate the effectiveness of collective consultation in your corporation?

6. How would you evaluate the effectiveness of employee directors and the employee supervisorS system?

7. How would you evaluate the effectiveness of grass-roots democratic participation institutions, such as democratic deliberation meetings, democratic forums, democratic management panels, etc.? 
Table 1 Variables used in the present study (Continued)

\begin{tabular}{ll}
\hline $\begin{array}{l}\text { Variable Name } \\
\text { gentrol Variables }\end{array}$ & Description \\
$\begin{array}{ll}\text { college } \\
\text { union } \\
\text { membership }\end{array}$ & high school and below $=0$; college and above $=1$ \\
$\begin{array}{l}\text { worker } \\
\text { representative }\end{array}$ & not worker representative $=0$; worker representative $=1$ \\
regular worker & dispatched worker $=0$; regular worker $=1$ \\
tenure & number of years the respondent has worked for this employer \\
city resident & rural $=0$; city $=1$ \\
marital status & single $=0$; other $=1$ \\
job position & workers $=1$; technicians $=2$; managerial staff $=3$ \\
\hline
\end{tabular}

and validated in Chinese mainland. To. A total of 15 items are used to represent five dimensions of OCB in this company: altruism, conscientiousness, identification with the company, interpersonal harmony, and protecting company resources. Example items include "Willing to assist new colleagues in adjusting to the work environment; willing to help colleagues solve work-related problems" $(\alpha=0.93)$. These items are rated by supervisors on a scale ranging from 1 ("strongly disagree") to 6 ("strongly agree").

\section{Independent variable}

We measure democratic management effectiveness as perceived by employees using seven items $(\alpha=0.90)$ rated by employees on an evaluation scale ranging from 1 ("very bad") to 4 ("very good"). Because perceived democratic management effectiveness has never been measured before, we develop the items through analyzing the key aspects of democratic management in public documents, including government regulations, provincial laws, company reports and prior research, and through interviews with Chinese IR scholars and union chairs. Seven aspects of democratic management are identified as central to the concept of democratic management. For example, the workers congress is the elemental form of democratic management in support of employee participation in firm management, employees' rights protection and corporate development. Thus, consistent with the documents and interviews, we develop items tapping the specific aspects of democratic management that are deemed important for the evaluation of democratic management: "How would you evaluate the effectiveness of the workers' congress, the institution of OCA, rationalization proposals, factory director reception day and factory director mail box,' collective consultation,' 'employee director and employee supervisor system, and grass-roots democratic participation institution". Principal components analysis yields a single factor for the construct. Table 2 lists the 7 items, and their loadings, and Table 3 gives summary factor statistics.

\section{Control variables}

We control for the usual demographics (gender, marital status), and for education (measured in two categories: high school and below; college and above). We combine the two categories of education "lower than high school" and "high school" because less than $5 \%$ of respondents receive lower than high school degree. We also control for 
Table 2 Results of factor analysis

\begin{tabular}{lc}
\hline Items & Factor \\
& 1 \\
\hline How would you evaluate the effectiveness of workers' congresses in general? & 0.74 \\
How would you evaluate the effectiveness of the institution of OCA & 0.72 \\
(e.g., open information through notice boards, workplace intranet, etc.)? & 0.71 \\
How would you evaluate the effectiveness of rationalization proposals? & 0.76 \\
How would you evaluate the effectiveness of factory director reception day & \\
and factory director mail box? & 0.79 \\
How would you evaluate the effectiveness of collective consultation in your corporation? & 0.77 \\
How would you evaluate the effectiveness of employee directors and the & \\
employee supervisor system? & 0.81 \\
How would you evaluate the effectiveness of grass-roots democratic participation & \\
institutions, such as democratic deliberation meetings, democratic forums, & \\
democratic management panels, etc?
\end{tabular}

work tenure, job position (measured in three categories: workers, technicians and managerial staff) and some identity variables (union membership, dispatched worker/regular worker, worker representative, Hukou (household registration status)). These control variables are included in the models because they are found correlated to employee performance and OCB in previous studies.

\section{Moderator}

An employee's identity as a regular worker is measured by a dummy variable equal to 1 for regular worker and 0 for dispatched worker.

\section{Analysis strategy}

Our analyses are conducted on individual level variables, with every employee embedded in a workshop. Such groupings call into question whether the individual level data are independent. Therefore, we first employ HLM analyses to explicitly examine the independence resulting from workshop $(n=29)$ groupings (Raudenbush and Bryk, 2002). For each dependent variable in the study, we run a set of null models without predictors. The between-workshop variance for dependent variables are significantly different from zero, indicating that the variance attributable to the workshop level is significant in explaining variance in individual-level dependent variables. Therefore, a random effect model clustered at the group level is appropriate for the research. Second, we use a random effect maximum likelihood estimation ${ }^{5}$ to conduct analyses grouping by workshop to determine the significance of perceived democratic management in predicting employee job performance and OCB. Third, we add interaction effects to the model and test for additional explained variance.

To test the validity of perceived democratic management effectiveness, we run an exploratory factor analysis on the 7 items of the perceived effectiveness of democratic management in a pilot sample of 281 in an automobile plant, with the items loaded on

Table 3 Summary factor statistics

\begin{tabular}{llll}
\hline Factor & Eigenvalue & Percentage of variance explained & Cumulative percentage of variance explained \\
\hline 1 & 4.00 & 100.1 & 100.1 \\
\hline
\end{tabular}


one factor. We then conduct CFA with the initial values of loadings from the Bollen (1996) 2SLS estimation procedure, with factor variances and covariances obtained from the variances of the scaling variables, and error variances obtained by assuming indicator reliabilities of 0.5 .

\section{Results}

Table 4 shows the correlations, means, and standard deviations for the study variables. Perceived democratic management effectiveness is positively associated with employee job performance $(r=0.22, p<0.001)$ and organizational citizenship behaviors $(r=0.31$, $p<0.001)$. Additionally, employment type $(r=0.21, p<0.001)$ is significantly associated with employee job performance. As well, employment type is also positively and significantly associated with $\mathrm{OCB}(r=0.21, p<0.001)$. Most control variables are correlated to the two dependent variables. However, marital status is not significantly associated with their $\mathrm{OCB}(r=-0.06$, n.s.), nor is job position significantly related to OCB $(r=0.03$, n.s.).

Null models are run for two individual-level dependent variables. Resulting ICC(1) values and associated chi-square tests revealed that $29 \%$ of the variance in employee job performance resides between workshops $\left(\chi^{2}[30]=373.8, p<0.001\right)$; $45 \%$ of the variance in OCB resides between workshops $\left(\chi^{2}[30]=735.30, p<0.001\right)$. Accordingly, we used random effect to predict employee job performance and OCB (Hypothesis 1-3).

We run a random effect model for perceived democratic management effectiveness. We enter the control variables as predictors for perceived democratic management effectiveness. The results (see Table 5 ) show that non-single employees $(b=0.13$, $p<0.05)$ are more likely to perceived democratic management as effective and single employees and technicians are more likely to perceive democratic management as effective $(b=0.11, p<0.05)$ than other workers. Although work tenure is significantly associated with perceived democratic management effectiveness $(b=-0.01, p<0.01)$, the effect size is small.

The result EFA shows that the 7 items of perceived democratic management load on one factor, indicating that it is reasonable to use it as independent variable. To confirm its validity, we further run a CFA and the results show a reasonable fit to the one factor model. Although $\chi 2$ rejects the null of good fit, the sample size of 988 tends to show significant results. Other indices of fit show reasonably good fit (RMSEA $=0.0473 ; 90 \%$ $\mathrm{CI}=(0.0308,0.0646) ; \mathrm{TLI}=0.9873 ; \mathrm{CFI}=0.9916 ; \mathrm{RMSR}=0.0086)$.

We propose in Hypothesis 1a that perceived democratic management effectiveness is positively associated with employee job performance. To test the hypothesis, we enter the control variables (gender, age, college degree, union membership, regular worker, marital status, job position, work tenure, residential identity and worker representative) and perceived democratic management effectiveness. As shown in Model 1 in Table 6, the hypothesis is supported. Perceived democratic management effectiveness is significantly and positively associated with employee job performance $(b=0.11, p<0.01)$. These predictors explain $15 \%$ of the available within group variance $(71 \%)$ in employee job performance $\left(R^{2}=0.150\right)$.

We conduct the same procedure to test Hypothesis $1 \mathrm{~b}$, that perceived democratic management effectiveness is positively associated with OCB. We enter the same group of control variables and perceived democratic management effectiveness. As shown in 


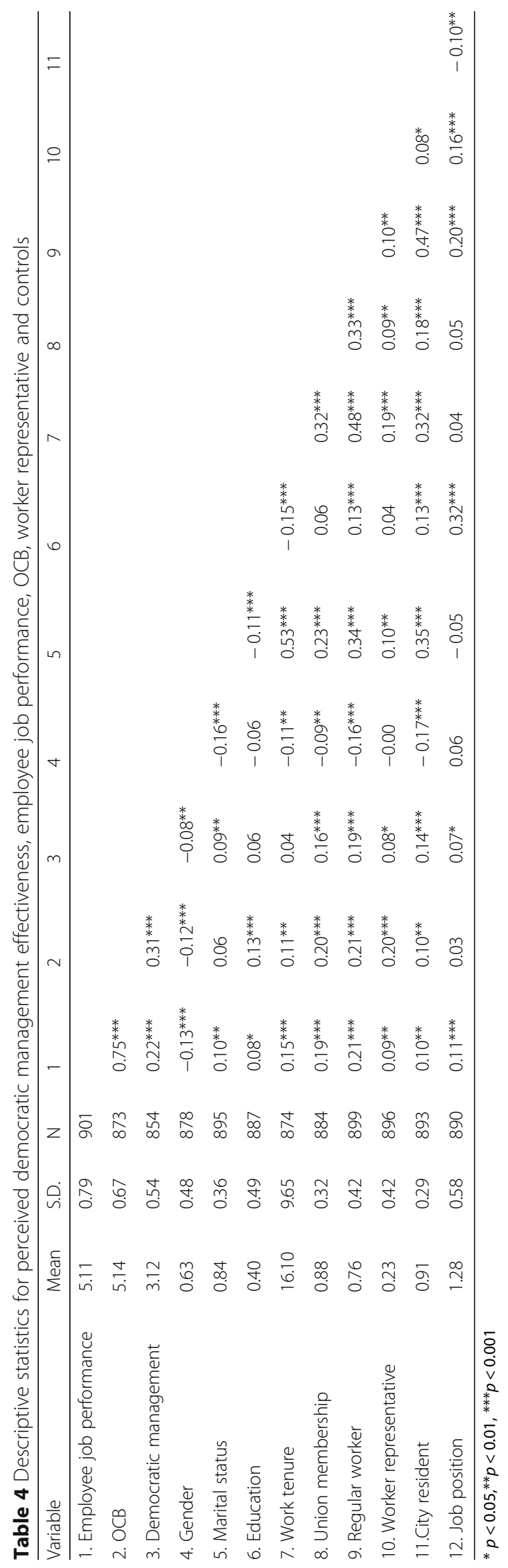


Table 5 Results of random effect analysis corrected for cluster effect at workshop for perceived democratic management effectiveness

\begin{tabular}{ll}
\hline Variable & Perceived DME \\
\hline Gender & Co-efficient \\
College degree & $-0.01(0.04)$ \\
Union member & $-0.04(0.04)$ \\
Worker representative & $0.05(0.07)$ \\
Regular worker & $0.08^{+}(0.04)$ \\
Work tenure & $-0.01(0.06)$ \\
City resident & $-0.01^{* *}(0.00)$ \\
Marital status & $-0.01(0.08)$ \\
Job position (technician) & $0.13^{*}(0.06)$ \\
Job position (managerial) & $0.11^{*}(0.06)$ \\
$N$ & $0.10(0.07)$ \\
Chi-Square & 726 \\
Degree of freedom & 18.17 \\
\hline
\end{tabular}

${ }^{+} p<0.1,{ }^{*} p<0.05,{ }^{* *} p<0.01$

Table 6 Results of random effect analysis corrected for cluster effect at workshop for employee job performance and $\mathrm{OCB}$

\begin{tabular}{|c|c|c|c|c|}
\hline & \multicolumn{2}{|c|}{ Employee Job Performance } & \multicolumn{2}{|l|}{ OCB } \\
\hline & Main Effect & Moderation & Main Effect & Moderation \\
\hline Variable & Model 1 & Model 2 & Model 3 & Model 4 \\
\hline Intercept & $4.75(0.21)$ & $5.33(0.30)$ & $4.88(0.17)$ & $5.59(0.24)$ \\
\hline Gender & $-0.03(0.05)$ & $-0.04(0.05)$ & $-0.01(0.04)$ & $-0.02(0.04)$ \\
\hline College degree & $0.05(0.05)$ & $0.05(0.05)$ & $0.09^{*}(0.04)$ & $0.09^{*}(0.04)$ \\
\hline Union member & $-0.02(0.09)$ & $-0.03(0.09)$ & $-0.05(0.07)$ & $-0.05(0.07)$ \\
\hline Worker representative & $0.03(0.06)$ & $0.03(0.06)$ & $-0.01(0.04)$ & $-0.01(0.04)$ \\
\hline Regular worker & $-0.03(0.08)$ & $-0.87^{* *}(0.32)$ & $-0.03(0.06)$ & $-1.07^{* * *}(0.06)$ \\
\hline Work tenure & $0.00(0.00)$ & $0.00(0.00)$ & $0.00(0.00)$ & $0.00(0.00)$ \\
\hline City resident & $-0.03(0.10)$ & $-0.01(0.10)$ & $-0.03(0.08)$ & $-0.01(0.08)$ \\
\hline Marital status & $0.07(0.08)$ & $0.09(0.08)$ & $-0.02(0.06)$ & $0.01(0.06)$ \\
\hline Job position (technician) & $0.24 * * *(0.07)$ & $0.23^{* *}(0.07)$ & $0.12^{*}(0.06)$ & $0.11^{+}(0.06)$ \\
\hline Job position (managerial) & $0.19^{+}(0.10)$ & $0.19^{+}(0.10)$ & $0.09(0.08)$ & $0.10(0.08)$ \\
\hline Perceived democratic management effectiveness & $0.11^{*}(0.05)$ & $-0.08(0.09)$ & $0.10^{* *}(0.04)$ & $-0.14^{*}(0.07)$ \\
\hline $\begin{array}{l}\text { Regular worker } \times \text { Perceived democratic } \\
\text { management effectiveness }\end{array}$ & & $0.27^{* *}(0.10)$ & & $0.33^{* * *}(0.08)$ \\
\hline N & 710 & 710 & 689 & 689 \\
\hline Chi-Square & 23.94 & 30.87 & 21 & 37.21 \\
\hline Degree of freedom & 11 & 12 & 11 & 12 \\
\hline
\end{tabular}

${ }^{+} p<0.1{ }^{*} p<0.05{ }^{* *} p<0.01{ }^{* * *} p<0.001$ 
Model 3 in Table 6, the hypothesis is supported. Perceived democratic management effectiveness is significantly and positively associated with OCB $(b=0.10, p<0.001)$. These predictors explain $12 \%$ of the available within group variance $(55 \%)$ in employee job performance $\left(R^{2}=0.12\right)$.

To study the moderating effect of employment type, we propose in Hypothesis 2 that employment type moderates the relations between perceived democratic management effectiveness and job performance, such that the relationship between job performance and perceived democratic management effectiveness will be negative for dispatched workers. As shown in Model 2 in Table 6, the interaction between perceived democratic management effectiveness and employment type is significantly related to employee job performance $(b=0.27, p<0.01)$. To assess whether the forms of these interactions are consistent with our hypotheses, we plot the interactions according to the guidelines provided by Aiken and West (1991), plotting the independent variables at a high and low level (one standard deviation above and below the mean). As shown in Fig. 2, the relationship between perceived democratic management effectiveness and employee job performance when the employees are dispatched workers is in the predicted direction. These results are consistent with Hypothesis 2.

Similarly, we propose in Hypothesis 3 that employment type moderates the relationship between perceived democratic management effectiveness and OCB, such that the relationship between citizenship behaviors and their perceived democratic management effectiveness will be negative for dispatched employees. As shown in Model 4 in Table 6, the interaction between perceived democratic management effectiveness and regular employment is significantly related to OCB $(b=0.33, p<0.001)$. Figure 3 displays that the relationship between perceived democratic management effectiveness and OCB when the employees are dispatched workers is in the predicted direction. These results offer support for Hypothesis 3.

To further clarify the interaction effects of the nature of disputes, we examine separate simple slopes depicting the relationship between perceived democratic management and the task performance. Figure 2 shows that the relationship is negative and

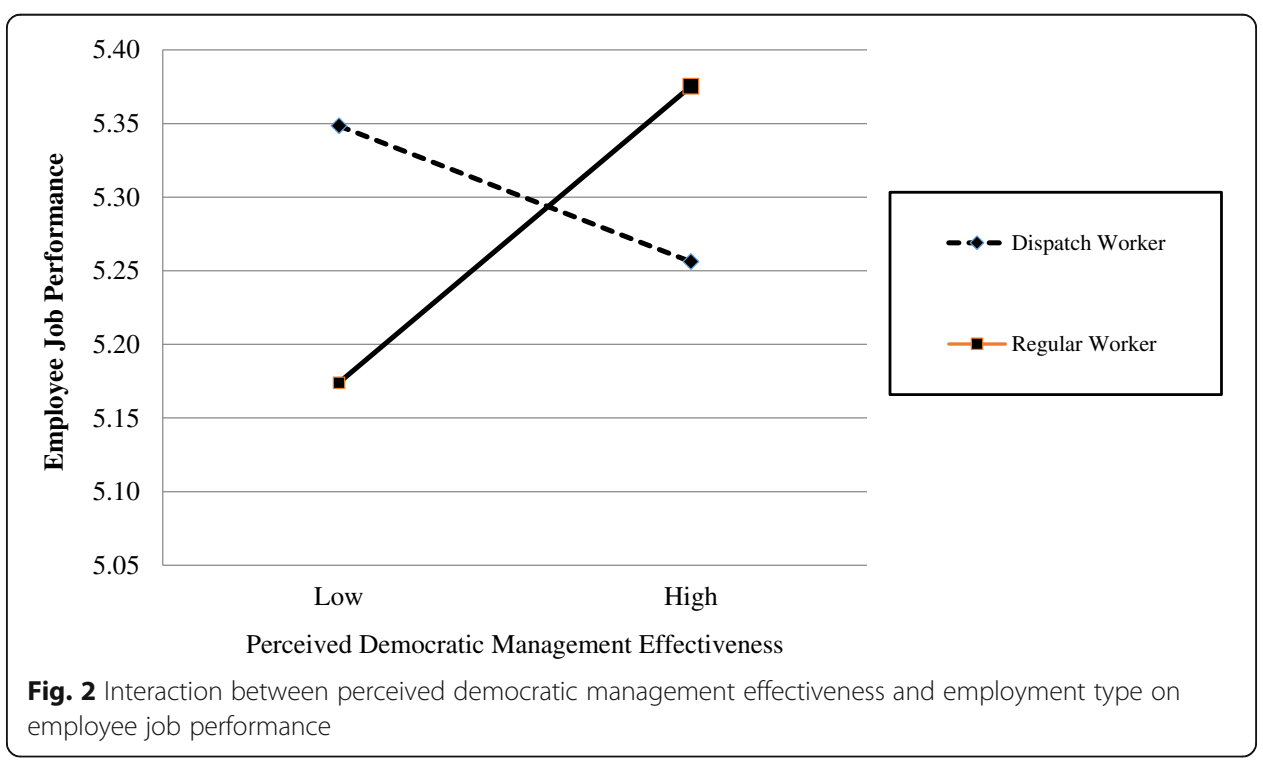




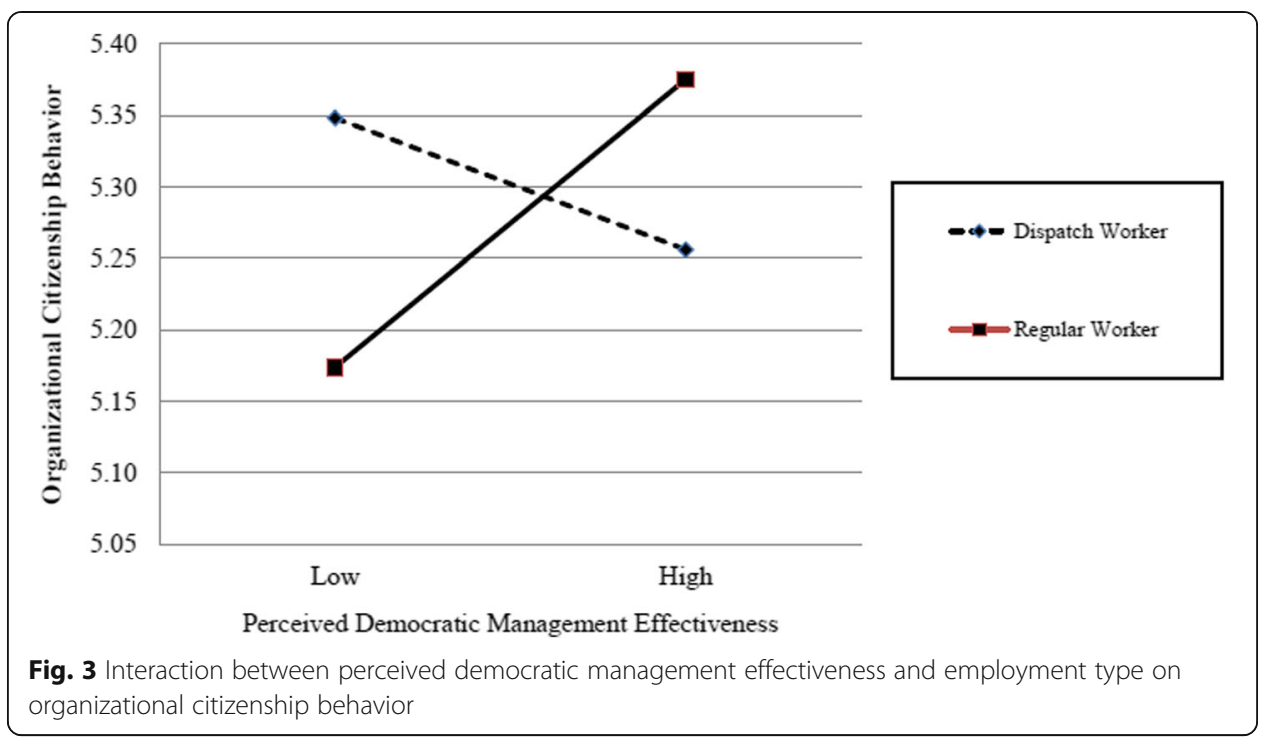

significant for dispatched workers $(b=-0.08, p<0.01)$ and positive and significant for contract workers $(b=0.19, p<0.01)$. The slopes of the two lines are significantly different $(t=-546.05, p<0.001)$. The above results, taken together, provide support for Hypothesis 2. As for the relationship between perceived democratic management and OCB, Fig. 3 shows that the relationship is negative and significant for dispatched workers $(b=-0.14, p<0.01)$ and positive and significant for regular workers $(b=0.19$, $p<0.01)$. The slopes of the two lines are significantly different $(t=-576.48, p<0.001)$. Thus, Hypothesis 3 is supported.

\section{Discussion and conclusion}

The empirical results support the idea that democratic management matters to the firm. Employees of different employment types perceive democratic management effectiveness differently. Perceived democratic management effectiveness is positively associated with employees' job performance and citizen behaviors. As indicated in our analysis, for dispatched workers who have less voice and a weaker bond with the firm, their perception of the effectiveness of democratic management can be negatively related to employee job performance and citizen behaviors, indicating the importance of job security in supporting the effects of democratic management. Democratic management is not only beneficial for the well-being of employees; but also benefit for the firm with regards to employee performance, as suggested in this paper.

The limitations of the analysis include the sampling and data collecting procedure of the research. It is difficult to fully control the procedure of conducting surveys due to the workplace environment of the petrochemical firm. Even though we ask the union representative to process the survey distribution and collection, it is possible that employees may have had concerns and were not honest about their perceptions about democratic management policies. In particular, dispatched workers are often at a disadvantage in this situation, and they may tend to give high evaluations to the survey questions to please the union representatives. Future research may look at the effects of democratic management perception on performance and OCB in non-SOEs. The mechanism through which the perception has an effect may be quite different because 
employees in private firms may be less influenced by party or patriotism, but are more likely to be influenced by market-driven values.

As well, the employers and managers who support some form of participation hope to enhance employee job satisfaction, or even contribute to productivity, and thus increase productivity and profits. Empirical work could use objective productivity measures, such as sales per person, to evaluate employee performance. Furthermore, future research could investigate democratic management beyond the individual level, and examine its implications on team performance and, most significantly, firm performance.

\section{Endnotes}

${ }^{1}$ The Interpretation of the Supreme People's Court on Several Issues about the Application of Laws for the Trial of Labor Dispute Cases, Article 19.

${ }^{2} \mathrm{SOE}$ reform has been taking place since 1978 and reached its peak during the 1990s and early 2000s. The reforms were intended to privatize most medium- and small-sized SOEs to build a competitive market. The direct effect of these reforms was liquidation of many SOEs, which led to huge lay-offs.

${ }^{3}$ Welfare housing is built on company-owned land and thus is sold at a price lower than the market price to employees.

${ }^{4}$ Workshop in this paper is used to indicate an administrative level. The corporation is comprised of several different plants conducting different businesses, including heavy machine manufacturing, petroleum extraction, water supply, etc. Each plant is divided into several divisions, such as workshop, maintenance team, department, etc.

${ }^{5}$ To solve the problem of non-normality of dependent variables, we also conductrandom effect Tobit regression grouping by workshops and mixed effect Poisson regression grouping by workshop, and both results are consistent with the results of random effect maximum likelihood model.

Availability of data and materials

The data of 988 matching surveys of both workers and their supervisors were collected from a state-owned petrochemical firm in the central region of China. Due to the signed confidentiality agreement with the company, that data will not be shared.

Authors' contributions

The author read and approved the final manuscript.

Competing interests

The author declares that she has no competing interests.

\section{Publisher's Note}

Springer Nature remains neutral with regard to jurisdictional claims in published maps and institutional affiliations.

Received: 19 October 2017 Accepted: 17 May 2018

Published online: 20 June 2018

References

Addison, J., Siebert, S., Wagner, J., \& Wei, X. (2000). Worker participation and firm performance: Evidence from Germany and Britain. British Journal of Industrial Relations, 38(1), 7-48.

Addison, J. T., Schnabel, C., \& Wagner, J. (2001). Works councils in Germany: Their effects on establishment performance. Oxford Economic Papers, 53(4), 659-694.

Addison, J. T., Schnabel, C., \& Wagner, J. (2004). The course of research into the economic consequences of German works councils. British Journal of Industrial Relations, 42(2), 255-281.

Addison, J. T., \& Wagner, J. (1997). The impact of German works councils on profitability and innovation: New evidence from micro data. Jahrbücher für Nationalökonomie und Statistik, 216(1), 1-20.

Ashford, S. J., Lee, C., \& Bobko, P. (1989). Content, cause, and consequences of job insecurity: A theory-based measure and substantive test. Academy of Management journal, 32(4), 803-829. 
Bollen, K. A. (1996). An alternative two stage least squares (2sis) estimator for latent variable equations. Psychometrika, 61(1), 109-121.

Chen, M. S., \& Chan, A. (2004). Employee and union inputs into occupational health and safety measures in Chinese factories. Social Science and Medicine, 58(7), 1231-1245.

Chen, M. S., \& Chan, A. (2010). Occupational health and safety in China: The case of state-managed enterprises. International Journal of Health Services, 40(1), 43-60.

Clarke, S., Lee, C. H., \& Li, Q. (2004). Collective consultation and industrial relations in China. British Journal of Industrial Relations, 42(2), 235-254

Cooke, W. N. (1994). Employee participation programs, group-based incentives, and company performance: A unionnonunion comparison. Industrial \& Labor Relations Review, 47(4), 594-609.

Cotton, J. L., Vollrath, D. A., Froggatt, K. L., Lengnick-Hall, M. L., \& Jennings, K. R. (1988). Employee participation: Diverse forms and different outcomes. Academy of Management Review, 13(1), 8-22.

Cotton, J. L., Vollrath, D. A., Lengnick-Hall, M., \& Froggatt, K. L. (1990). Fact: The form of participation does matter-a rebuttal to Leana, Locke, and Schweiger. Academy of Management Review, 15(1), 147-153.

Deluga, R. J. (1994a). Supervisor trust building, leader-member exchange and organizational citizenship behaviour. Journal of Occupational \& Organizational Psychology, 67(4), 315-326.

Deluga, R. J. (1995). The relationship between attributional charismatic leadership and organizational citizenship behavior. Journal of Applied Social Psychology, 25(18), 1652-1669.

Deutsch, M. (1975). Equity, equality, and need: What determines which value will be used as the basis of distributive justice? Journal of Social Issues, 31(3), 137-149.

Farh, J. L., Podsakoff, P. M., \& Organ, D. W. (1990). Accounting for organizational citizenship behavior: Leader fairness and task scope versus satisfaction. Journal of Management, 16(4), 705-721.

Folger, R. (1977). Distributive and procedural justice: Combined impact of voice and improvement on experienced inequity. Journal of Personality \& Social Psychology, 35(2), 108-119.

Gallagher, M. E. (2005). Contagious capitalism. Princeton University Press.

Gouldner, A. W. (1960). The norm of reciprocity. American Sociological Review, 25, 165-167.

Gurdon, M. A., \& Rai, A. (1990). Codetermination and enterprise performance: Empirical evidence from West Germany. Journal of Economics and Business, 42(4), 289-302.

Hui, C., Law, K. S., \& Chen, Z. X. (1999). A structural equation model of the effects of negative affectivity, leader-member exchange, and perceived job mobility on in-role and extra-role performance: A Chinese case. Organizational Behavior and Human Decision Processes, 77(1), 3-21.

Konovsky, M. A., \& Organ, D. W. (1996a). Dispositional and contextual determinants of organizational citizenship behavior. Journal of Organizational Behavior, 17(3), 253-266

Konovsky, M. A., \& Pugh, S. D. (1994b). Citizenship behavior and social exchange. Academy of Management Journal, 37(3), 656-669.

Kuruvilla, S., Lee, C. K., \& Gallagher, M. E. (2011). From Iron Rice bowl to Informalization: Markets, workers, and the state in a changing China. Cornell University Press.

Leana, C. R. (1986). Predictors and consequences of delegation. Academy of Management Journal, 29(4), 754-774.

Levine, D. I. (1990). Participation, productivity, and the firm's environment. California Management Review, 32(4), 86-100.

Li, M. (2004). Workers' participation in management and firm performance: Evidence from large and medium-sized Chinese industrial enterprises. Review of Radical Political Economics, 36(3), 358-380.

Liu, W. (2007). Zhigong Minzhu Guanli Lilun yu Shijian (employee democratic management: Theories and practices). Zhongguo Laodong Shehui Baozhang Chubanshe (China Labor and Social Security Press).

Locke, E. A., \& Schweiger, D. M. (1979). Participation in decision-making: One more look. Research in Organizational Behavior, 1(10), 265-339.

Miller, K. I., \& Monge, P. R. (1986). Participation, satisfaction, and productivity: A meta-analytic review. Academy of Management Journal, 29(4), 727-753

Mitchell, T. R. (1973). Motivation and participation: An integration. Academy of Management Journal, 16(4), 670-679.

Mueller, S. (2011). Works councils and firm profits revisited. British Journal of Industrial Relations, 49(1), 27-43.

$\mathrm{Ng}, \mathrm{S}$. H. (1984). One brand of workplace democracy: The Workers' congress in the Chinese Enterprise. Journal of Industrial Relations, 26(1), 56-75.

Organ, D. W. (1988). Organizational citizenship behavior: The good soldier syndrome. Administrative Science Quarterly, $41(6)$, págs. 692-703.

Philion, S. (2007). Workers' democracy vs. privatization in China. Socialism and Democracy, 21(2), 37-55.

Schregle, J. (1970). Forms of participation in management. Industrial Relations: A Journal of Economy and Society, 9(2), 117-122.

Schweiger, D. M., \& Leana, C. R. (1986). Participation in decision making. Generalizing from laboratory to field settings, 147, 166.

Taylor, B., Chang, K., \& Li, Q. (2003). Industrial relations in China. Edward Elgar Publishing.

Van Dyne, L., \& Pierce, J. L. (2004). Psychological ownership and feelings of possession: Three field studies predicting employee attitudes and organizational citizenship behavior. Journal of Organizational Behavior, 25(4), 439-459.

VanYperen, N. W., Berg, A. E., \& Willering, M. C. (1999). Towards a better understanding of the link between participation in decision-making and organizational citizenship behaviour: A multilevel analysis. Journal of Occupational and Organizational Psychology, 72(3), 377-392.

Vroom, V. H., \& Jago, A. G. (1988). Managing participation: A critical dimension of leadership. Journal of Management Development, 7(5), 32-42.

Wagner, J. A. (1994). Participation's effects on performance and satisfaction: A reconsideration of research evidence. Academy of Management Review, 19(2), 312-330.

Walder, A. G. (1986). Communist Neo-Traditionalism: Work and Authority in Chinese Industry. Berkeley. University of California Press.

Wilpert, B. (1991). Property, ownership, and participation: On the growing contradictions between legal and psychological concepts. International handbook of participation in organizations: For the study of organizational democracy, co-operation, and self management, 2, 149-164. 
Wrzesniewski, A., \& Dutton, J. E. (2001). Crafting a job: Revisioning employees as active crafters of their work. Academy of Management Review, 26(2), 179-201.

Yu, A. L. (2011). From "master" to "menial": State-owned enterprise workers in contemporary China. Working USA, 14(4), 453-472.

Zhang, L. (2008). Lean production and labor controls in the Chinese automobile industry in an age of globalization'. International Labor and Working-Class History, 73(1), 1-21.

Zhu, X., \& Chan, A. (2005). Staff and Workers' representative congress: An Institutionalized Channel for expression of employees' interests? Chinese Sociology \& Anthropology, 37(4), 6-33.

Submit your manuscript to a SpringerOpen ${ }^{\circ}$ journal and benefit from:

- Convenient online submission

- Rigorous peer review

Open access: articles freely available online

- High visibility within the field

- Retaining the copyright to your article

Submit your next manuscript at $\boldsymbol{s p r i n g e r o p e n . c o m ~}$ 